\title{
Knowledge About Hand Hygiene among Medical Students and Nursing Students in Masaka Regional Referral Hospital
}

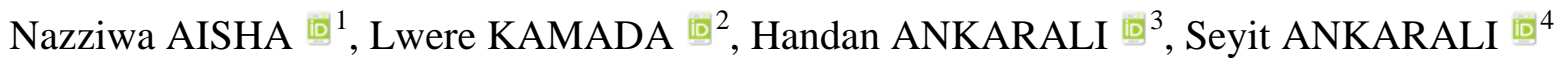

\begin{abstract}
Aim: The pathogenic bacterium on the hands of healthcare workers (HCWs) is considered as the main route of spread of hospital-acquired infections. This study determines the knowledge regarding hand hygiene among medical and nursing students in a Regional Referral Hospital.

Material and Methods: 100 students participated in the study. Data was collected using the World Health Organization hand hygiene knowledge questionnaire (revised 2009). The questionnaire contains questions on the participant's demographics, formal training in hand hygiene and questions to assess hand hygiene knowledge. Descriptive statistics of the variables were computed as Mean $\pm \mathrm{SD}$ and frequencies ( $\mathrm{n}, \%)$. The relationships between the categorical variables were investigated by using Pearson Chi-Square test. Also independent-samples t-test were used to investigate the difference between groups with regard to numerical variables. In all calculations, $\mathrm{P}<0.05$ is considered as the level of statistical significance. Statistical analysis was performed using SPSS 20 (IBM SPSS statistics, Somers, NY).

Results: $90.8 \%$ of the students reported receiving formal training in hand hygiene. However only $2 \%$ of the students had good knowledge, $74 \%$ moderate knowledge and $24 \%$ low knowledge about hand hygiene. The study did not find any significant difference in the knowledge level between the students who had received formal training in hand hygiene and those who had not $(\mathrm{p}=0.392)$. Also, the mean knowledge score was not associated with gender $(\mathrm{p}=0.82)$, or profession ( $\mathrm{p}=0.179)$.

Conclusion: It is of importance to devise effective teaching methods that will help the students retain the knowledge on hand hygiene.
\end{abstract}

Keywords: Hand hygiene; medical students; nursing students; health students; Uganda.

\section{Masaka Bölge Sevk Hastanesindeki Tıp Öğrencileri ve Hemşirelik Öğrencileri Arasındaki El Hijyeni Hakkında Bilgi}

\section{ÖZ}

Amaç: Sağlık çalışanlarının elindeki patojenik bakteri, hastane kaynaklı enfeksiyonların ana yayılma yolu olarak kabul edilmektedir. Bu çalışma, bir Bölge Sevk Hastanesindeki tıp ve hemşirelik öğrencilerinin el hijyenine ilişkin bilgilerini belirlemektedir.

Gereç ve Yöntemler: Araştırmaya 44'ü tıp öğrencisi, 56'sı hemşirelik öğrencisi olan 100 öğrenci katılmıştır. Anket, katılımcının demografik bilgilerini, el hijyeni konusundaki resmi eğitimi ve el hijyeni bilgisini değerlendirmek için sorular içermektedir. Değişkenlerin tanımlayıcı istatistikleri Ortalama \pm SD ve frekanslar (n, \%) olarak hesaplandı. Kategorik değişkenler arasındaki ilişkiler Pearson Ki-Kare testi kullanılarak araştırıldı. Ayrıca, sayısal değişkenler açısından gruplar arasındaki farkı araştırmak için independent-samples t-testi kullanıldı. Tüm hesaplamalarda, istatistiksel anlamlılık düzeyi olarak p $<0,05$ kabul edildi. İstatistiksel analiz, SPSS 20 (IBM SPSS istatistikleri, Somers, NY) kullanılarak yapıldı.

Bulgular: El hijyeni konusunda öğrencilerin \% 2'si iyi, \% 74'ü orta düzeyde ve \% 24'ü düşük bilgiye sahipti. Araştırmada el hijyeni konusunda örgün eğitim almış öğrenciler ile almayanlar arasında bilgi düzeyinde anlamlı bir fark bulunmamıştır $(p=0,392)$. Ayrıca ortalama bilgi puanı cinsiyet $(p=0,82)$ veya meslek $(p=0,179)$ ile ilişkili değildi.

1 Department of Community Medicine, Habib Medical School, Islamic University, Kampala, UGANDA

2 Department of Community Medicine, Habib Medical School, Islamic University, Kampala, UGANDA

3 Department of Biostatistics and Medical Informatics, Medical Faculty, Istanbul Medeniyet University, Istanbul, TURKEY

4 Department of Physiology, Medical Faculty, Istanbul Medeniyet University, Istanbul, TURKEY 
Sonuç: Öğrencilerin el hijyeni konusundaki bilgilerini korumalarına yardımcı olacak etkili öğretim yöntemlerinin geliştirilmesi önemlidir.

Anahtar Kelimeler: El hijyeni; tıp öğrencisi; hemşirelik öğrencileri; sağlık öğrencileri; Uganda.

\section{INTRODUCTION}

Hand hygiene is universally acknowledged to be the single most important measure to prevent crosstransmission of microorganism from one patient to another and preventing Health Care Associated Infections (1). Alcohol-based hand disinfection represents the key infection control measure to prevent healthcareassociated infections and nosocomial transmission of pathogens. Epidemiologic studies have also continued to demonstrate the favourable cost-benefit ratio and positive effects of simple hand washing for preventing transmission of pathogens in health care facilities (2).

Although adherence to hand hygiene practices is considered as an integral part of quality health care and that it is a Joint Commission requirement that Centres for Disease Control and Prevention hand hygiene guidelines be implemented in hospitals, compliance among health care workers remains low (3-6).

Compliance to hand hygiene varies among professional categories, hospital wards, working conditions and according to definitions used in different studies. For example, in an outpatient clinic hand hygiene among physicians could be as low as $6.48 \%$, while in a paediatric oncology ward hand hygiene compliance rates of $53.4 \%, 42.5 \%$ and $32.6 \%$ are observed for nurses, doctors and other HCWs respectively $(7,8)$.

Studies have found the lack of compliance to handwashing to be due to allergies to hand washing products, insufficient knowledge among staff about risks and procedures, lack of appropriate equipment, the time required and casual attitudes among HCWs towards biosafety and low staff to patient ratio $(9,10)$. To improve hand hygiene practices, there is need for continuing medical education programs for all level of health care providers and easy access to hand hygiene measures $(11,12)$.

Medical and nursing students represent a big percentage of prospective $\mathrm{HCWs}$ with the potential to carry bacterium from one patient to another as they continuously move from one department to another during study. It is of importance to regularly improve hand hygiene compliance among these students. This study determines the knowledge regarding hand hygiene in this group and to assess the potential for optimizing education.

\section{MATERIAL AND METHODS \\ Study Aim and Design}

The current descriptive study is aimed at determining the hand hygiene knowledge among medical and nursing students. The study was carried out on 11th November 2021.

\section{Research Population and Sampling Method}

All final year students in a teaching hospital were invited to participate in the study. At the time of study, there were 60 medical students and 70 nursing students. 44 (73\%) medical students and $56(80 \%)$ nursing students participated in the study. The questionnaire was filled by all the students who consented to participate in the study.

\section{Data Collection Tools}

This study involved a questionnaire with 10 questions. The questions are based on the hand hygiene Knowledge Questionnaire for Health-Care Workers from the World Health Organization (WHO; revised version of August 2009 (13). It consists of 9 multiple choice questions with some having one correct choice and others a number of correct choices. To answer correctly, a respondent should mark all the correct answers. These 9 questions are used to evaluate the students' knowledge (knowledge score). Question 10 asks the participants for an estimate of hand hygiene compliance (in percentage) in clinical practice. Students are also asked to provide some social demographic characteristics like age and gender.

\section{Ethical Aspects}

The study was approved by the ethics committee of Islamic University in Uganda, written consent was signed by all participants in the study (RCC/FHS/20/005). Written approval was obtained from the hospital administration at the hospital where study is carried out.

\section{Statistical Analysis}

Descriptive statistics of the variables were computed as Mean \pm SD and frequencies (n, \%). The relationships between the categorical variables were investigated by using Pearson Chi-Square test. Also independent-samples t-test were used to investigate the difference between groups with regard to numerical variables. In all calculations, $\mathrm{P}<0.05$ is considered as the level of statistical significance. Statistical analysis was performed using SPSS 20 (IBM SPSS statistics, Somers, NY) (14).

\section{RESULTS}

\section{Demographics}

The study consisted of 100 students. $48 \%$ women with average age 28 years and $52 \%$ male with average age 29.7 years. 44 were medical students and 56 nursing students. Demographic information is summarized in Table $1.86 \%$ of the students reported that they used alcohol based hand rub regularly and $90.8 \%$ had received formal training in hand hygiene.

Table 1. Descriptive statistics of variables

\begin{tabular}{|l|c|c|}
\hline Variables & Categories & $\begin{array}{c}\text { n (\%) or } \\
\text { Mean } \pm \text { SD* }\end{array}$ \\
\hline \multirow{2}{*}{ Gender } & Female & $48(48)$ \\
\cline { 2 - 3 } Job & Male & $52(52)$ \\
\hline Hand Hygiene & Medical student & $44(44)$ \\
\cline { 2 - 3 } training & Nurse student & $56(56)$ \\
\hline \multirow{2}{*}{ Age } & Yes & $89(90.8)$ \\
\cline { 2 - 3 } & No & $9(9.2)$ \\
\cline { 2 - 3 } & female & $28.42 \pm 1.068$ \\
\cline { 2 - 3 } & male & $29.75 \pm 1.135$ \\
\hline
\end{tabular}




\section{Knowledge on Hand hygiene}

The hand hygiene knowledge of the participants is summarised in Table 2. There was significant difference in the average knowledge score between the nurses and doctors on answering the question 'What is the most frequent source of germs responsible for HCAI?' ( $\mathrm{P}=$ 0.018) and 'What is the recommended duration of hygienic hand disinfection in Uganda' $(\mathrm{P}=0.008)$.

Table 2. Responses to the hand hygiene knowledge questionnaire for health-care workers from the world health organization. data presented in ' $\mathrm{n}(\%)$ '

\begin{tabular}{|c|c|c|c|c|c|}
\hline Questions* & Responses & $\begin{array}{c}\text { MEDICAL } \\
\text { STUDENT } \mathrm{n}=44\end{array}$ & $\begin{array}{l}\text { NURSE } \\
\text { STUDENT } \mathrm{n}=56 \\
\end{array}$ & $\begin{array}{l}\text { TOTAL } \\
\mathrm{N}=100 \\
\end{array}$ & $\begin{array}{c}\mathrm{P} \\
\text { value }\end{array}$ \\
\hline $\begin{array}{l}\text { Which of the following is the main route } \\
\text { of the transmission of potentially harmful } \\
\text { germs between the patients? }\end{array}$ & \begin{tabular}{|l|} 
Healthcare workers hands \\
when not clean \\
- Air circulating in hospital \\
- Patients exposure to colonized \\
surfaces \\
- Sharing non-invasive objects \\
(e.g. stethoscope)
\end{tabular} & $10(23.3)$ & 11(19.6) & 42.9 & 0.707 \\
\hline $\begin{array}{l}\text { What is the most frequent source of germs } \\
\text { responsible for HCAI }\end{array}$ & $\begin{array}{ll}\text { - Hospital water system } \\
\text { - } \\
\text { - Germs present on or within } \\
\text { patient } \\
\text { - Hospital environment }\end{array}$ & $11(25.6$ & $27(48.2)$ & 73.8 & 0.018 \\
\hline $\begin{array}{l}\text { Which of the following hand hygiene } \\
\text { actions prevent transmission of germs to a } \\
\text { patient? }\end{array}$ & \begin{tabular}{|l|} 
Before a healthcare worker \\
touches a patient \\
- After a healthcare worker had \\
contact with a body fluid \\
- After a healthcare worker had \\
contact with the patient \\
surrounding \\
- Before a healthcare worker \\
performs an aseptic \\
procedure
\end{tabular} & $21(47.7)$ & $19(35.8)$ & 40 & 0.209 \\
\hline $\begin{array}{l}\text { Which of the following hand hygiene } \\
\text { actions prevents transmission of germs to } \\
\text { a healthcare worker? }\end{array}$ & \begin{tabular}{|l|} 
- After touching a patient \\
After a healthcare worker \\
had contact with a body fluid \\
- $\begin{array}{l}\text { Before a healthcare worker } \\
\text { performs an aseptic procedure }\end{array}$ \\
- After a healthcare worker \\
had contact with the patient \\
surrounding
\end{tabular} & 2(4.9) & $7(12.7)$ & 9 & 0.192 \\
\hline \multirow[t]{4}{*}{$\begin{array}{l}\text { Which of the following statements on } \\
\text { alcohol-based hand rub and hand washing } \\
\text { with soap and water are true? }\end{array}$} & $\begin{array}{l}\text { Hand rubbing is more rapid for } \\
\text { hand cleansing than handwashing } \\
\text { (true) }\end{array}$ & $34(81)$ & $42(77.8)$ & 76 & 0.792 \\
\hline & $\begin{array}{l}\text { Hygienic hand disinfection dries } \\
\text { the skin out more than hand } \\
\text { washing with soap (false) }\end{array}$ & $20(50)$ & $27(49.1)$ & 47 & 0.784 \\
\hline & $\begin{array}{l}\text { Hand rubbing is more effective } \\
\text { against germs than handwashing } \\
\text { (false) }\end{array}$ & $14(35)$ & $10(18.5)$ & 24 & 0.105 \\
\hline & $\begin{array}{l}\text { Hand washing and hand rubbing } \\
\text { are recommended to be } \\
\text { performed in sequence (false) }\end{array}$ & $29(76.3)$ & $30(68.2)$ & 59 & 0.213 \\
\hline $\begin{array}{l}\text { What is the recommended duration of } \\
\text { hygienic hand disinfection (in Uganda)? } \\
\text { (one answer only) }\end{array}$ & $\begin{array}{l}\text { - } 20 \text { seconds } \\
\text { - } 3 \text { seconds } \\
\text { - } 1 \text { minute } \\
\text { - } 10 \text { seconds }\end{array}$ & $8(20.5)$ & $23(46.9)$ & 31 & 0.008 \\
\hline \multirow{6}{*}{$\begin{array}{l}\text { Which type of hand hygiene method is } \\
\text { required in these situations: rubbing }(\mathbf{R}) \text {, } \\
\text { washing }(\mathbf{W}) \text { or none }(\mathrm{N}) \text { ? }\end{array}$} & Before palpitation of abdomen $\mathbf{R}$ & $28(66.7)$ & $44(78.6)$ & 72 & 0.099 \\
\hline & Before giving an injection $\mathbf{R}$ & $23(54.8)$ & $28(50.9)$ & 51 & 0.821 \\
\hline & After emptying a bed pan $\mathbf{W}$ & $10(25)$ & $15(25.5)$ & 25 & 0.582 \\
\hline & $\begin{array}{l}\text { After removing examination } \\
\text { gloves } \mathbf{R} / \mathbf{W}\end{array}$ & $7(15.9)$ & $12(21.8)$ & 19 & 0.257 \\
\hline & After making a patient's bed $\mathbf{R}$ & $14(32.6)$ & $13(24.1)$ & 27 & 0.336 \\
\hline & After visible exposure to blood $\mathbf{W}$ & $23(53.5)$ & $27(49.1)$ & 50 & 0.68 \\
\hline
\end{tabular}


Table 2. Responses to the hand hygiene knowledge questionnaire for health-care workers from the world health organization. data presented in ' $\mathrm{n}(\%)$ ' (continued)

\begin{tabular}{|c|c|c|c|c|c|}
\hline \multirow{4}{*}{$\begin{array}{l}\text { What should be avoided as associated with } \\
\text { increased likelihood of colonization of } \\
\text { hands with harmful germs? }\end{array}$} & Wearing rings on the hands (yes) & $32(74.4)$ & $44(78.6)$ & 76 & 0.497 \\
\hline & Damaged skin (yes) & $37(86)$ & $39(70.9)$ & 76 & 0.093 \\
\hline & $\begin{array}{l}\text { Wearing artificial fingernails } \\
\text { (yes) }\end{array}$ & $36(83.7)$ & $43(76.8)$ & 79 & 0.540 \\
\hline & Regular use of skin care lotion (no) & $28(66.7$ & $39(70.9)$ & 67 & 0.526 \\
\hline $\begin{array}{l}\text { How high do you estimate overall } \\
\text { compliance to hygienic hand disinfection } \\
\text { in healthcare settings in percent?(Results } \\
\text { as mean percentage) }\end{array}$ & & 74.83 & 78.49 & 76.87 & 0.548 \\
\hline
\end{tabular}

indicated in bold.

Table 3. Students' knowledge level

\begin{tabular}{|l|c|c|c|c|}
\hline $\begin{array}{l}\text { Hand hygiene } \\
\text { Knowledge }\end{array}$ & $\begin{array}{c}\text { Medical } \\
\text { students } \\
\mathrm{n}(\%)\end{array}$ & $\begin{array}{c}\text { Nurse } \\
\text { student } \\
\mathrm{n}(\%)\end{array}$ & $\begin{array}{c}\text { Total } \\
\mathrm{n}(\%)\end{array}$ & P value \\
\hline Good & $0(0)$ & $2(3.6)$ & $2(2)$ & \multirow{2}{*}{0.916} \\
\cline { 1 - 4 } Moderate & $33(75)$ & $41(73.2)$ & $74(74)$ & \\
\cline { 1 - 4 } & $11(25)$ & $13(23.2)$ & $24(24)$ & \\
\hline
\end{tabular}

The Nurses seemed to have more knowledge on these questions than the doctors. The question that had most incorrect answers is "Which of the following hand hygiene actions prevents transmission of germs to a healthcare worker?' Only $9 \%$ of the students got this question correct. This was followed by 'What is the recommended duration of hygienic hand disinfection (in Uganda)?' with $31 \%$ of participants getting a correct answer. $45.5 \%$ of the medical students and $37.5 \%$ of nurses said it was 10 seconds.

\section{Comparison of Participants Knowledge score.}

Overall percentage $2 \%$ have good knowledge, $74 \%$ moderate knowledge and $24 \%$ low knowledge. Table 4 shows the comparison of knowledge according to age, gender, profession and whether received training on hand hygiene. Female performed better than the male with 56 \pm 10.3 compared to $55.7 \pm 10$ of the male. Also those who did not receive formal training in hand hygiene performed better than those who received formal training in hand hygiene. Nurses performed better than Medical students; $56.1 \pm 11.2$ compared to 55.6 \pm 8.7. The knowledge score did not differ significantly among all the comparisons.

Table 4. Comparison of knowledge scores.

\begin{tabular}{|c|c|c|c|}
\hline \multirow{2}{*}{ Gender } & Female & $\begin{array}{c}\text { Knowledge } \\
\text { score } \\
\text { Mean } \pm \text { SD }\end{array}$ & \multirow{2}{*}{ P value } \\
\cline { 2 - 3 } & Male & $55.7 \pm 10.3$ & \multirow{2}{*}{0.820} \\
\hline \multirow{3}{*}{ HH training } & Yes & $55.7 \pm 9.6$ & \multirow{2}{*}{0.392} \\
\cline { 2 - 3 } & No & $59 \pm 16.5$ & \multirow{2}{*}{0.179} \\
\hline \multirow{3}{*}{ Profession } & $\begin{array}{c}\text { Medical } \\
\text { student }\end{array}$ & $55.6 \pm 8.7$ & \multirow{2}{*}{$0.1 \pm 11.2$} \\
\cline { 2 - 3 } & Nurse student & $56.1 \pm 2$ \\
\hline
\end{tabular}

\section{Opinion of participants}

Question 10 assessed the opinion of participants on what is the average percentage of hospitalized patients who will develop a health care associated infection (between 0 and 100). The average was found to be $40.21 \pm 24.1$.

\section{DISCUSSION}

In this study, the students had moderate level of knowledge. Other studies also had similar results. The average knowledge level in our study is higher compared to another study in Uganda but lower than other studies in developed countries (15). Although $86 \%$ of students reported receiving hand hygiene training their average knowledge level was lower than those who had not received training. This finding is in line with a study in India (16) where those who received formal training had lower average score than those who hadn't and also in line with a study by Calabro et al (17).

A study in Turkey also found that despite regular $\mathrm{HH}$ trainings, healthcare workers could not differentiate when $\mathrm{HH}$ was not required which suggested failure to understand $\mathrm{HH}$ rationale (12). This study may necessitate another study of attitude and practices towards hand hygiene to better explain the result. It also necessitates that it is needed to evaluate our hand hygiene training course and reduce the time between training programs.

The average knowledge score of the nurses were higher than the medical students although not significantly different. It seems hand hygiene is considered more central in nursing curriculum than medical curriculum. Our results show no difference in knowledge score between male and female. This is similar to some studies (16) but different from (18).

An in-depth analysis reveals that the students answer to Question 1, 'Which of the following is the main route of the transmission of potentially harmful germs between the patients?' is poorly answered. Only $21 \%$ got a correct answer which is; Healthcare workers hands when not clean, while $35 \%$ believed it is the air circulating in hospital and $36 \%$ believed patients exposure to colonised surfaces.

Another area that needs to be emphasised during training is what kind of hand hygiene method is to be done in different situations for example; there is no student who got all correct answers to question seven. Other studies however showed that most of the health care workers were aware of the conditions before or after when $\mathrm{HH}$ activity has to be performed (19). The separate role of 
hand washing compared to hygienic hand disinfection needs to be clear.

Our study is limited to final year medical students and nurses in one institution In Uganda. The results may thus not be generalised to other students.

\section{Funding}

This research received funding from Islamic Development Bank Phase 11 through Islamic University in Uganda.

Authors's Contributions: Idea/Concept: N.A.; Design: L.K.; Data Collection and/or Processing: L.K.; Analysis and/or Interpretation: N.A.; Literature Review: N.A., H.A., S.A.; Writing the Article: H.A., S.A.; Critical Review: H.A., S.A.

\section{REFERENCES}

1. Loftus MJ, Guitart C, Tartari E, Stewardson AJ, Amer F, Bellissimo-Rodrigues F, et al. Hand hygiene in low- and middle-income countries. Int $\mathbf{J}$ Infect Dis. 2019; 86: 25-30.

2. Wohrley JD, Bartlett AH. The Role of the Environment and Colonization in HealthcareAssociated Infections. In: Healthcare-Associated Infections in Children. Springer International Publishing; 2019. p. 17-36.

3. Bezerra TB, Valim MD, Bortolini J, Ribeiro RP, Marcon SR, Moura MEB. Adherence to hand hygiene in critical sectors: Can we go on like this? Journal of Clinical Nursing. 2020; 29 (13-14): 2691-8.

4. Vikke HS, Vittinghus S, Giebner M, Kolmos HJ, Smith K, Castren M, et al. Compliance with hand hygiene in emergency medical services: An international observational study. Emergency Medicine Journal. 2019; 36(3): 171-5.

5. Ogwang M, Paramatti D, Molteni T, Ochola E, Okello TR, Ortiz Salgado JC, et al. Prevalence of hospital-associated infections can be decreased effectively in developing countries. Journal of Hospital Infection. 2013; 84(2): 138-42.

6. Abuosi AA, Akoriyea SK, Ntow-Kummi G, Akanuwe J, Abor PA, Daniels AA, et al. Hand hygiene compliance among healthcare workers in Ghana's health care institutions: An observational study. Journal of Patient Safety and Risk Management. 2020; 25(5): 177-86.

7. Kato H, Takeda R, Ideno Y, Suzuki T, Sano K, Nakamura K. Physicians' compliance for hand hygiene in medical outpatient clinics: automated hand-hygiene monitoring with touch sensor and wireless internet. American Journal of Infection Control. 2021; 49(1): 50-4.

8. Kashyap B, Gupta K, Gomber S, Gupta N, Bhardwaj A, Singh N, et al. Hand hygiene compliance among health care workers in pediatric oncology ward of a tertiary care hospital: A cross sectional observational study. Indian Journal of Medical Specialities. 2017; 8(4): 197-9.

9. Pittet D. Improving adherence to hand hygiene practice: A multidisciplinary approach. In: Emerging Infectious Diseases [Internet]. Centers for Disease Control and Prevention (CDC); 2001. p. 234-40.
10. Sands M, Aunger R. Determinants of hand hygiene compliance among nurses in US hospitals: A formative research study. Chughtai AA, editor. PLOS ONE. 2020; 15(4): e0230573.

11. Ahmed J, Malik F, Memon ZA, bin Arif T, Ali A, Nasim S, et al. Compliance and knowledge of healthcare workers regarding hand hygiene and use of disinfectants: A study based in Karachi. Cureus. 2020; 12(2): e7036.

12. Sili U, Ay P, Bilgin H, Hidiroglu S, Korten V. Hand hygiene knowledge, perception and practice of healthcare workers in a Turkish university hospital intensive care unit. J Infect Dev Ctries. 2019; 13(8): 744-7.

13. World Health Organization (WHO), Tools for evaluation and feedback. Available from: https://www.who.int.

14. IBM Corp. Released 2011. IBM SPSS Statistics for Windows, Version 20.0. Armonk, NY: IBM Corp. Available from: https://www.ibm.com.

15. Goyal A, Narula H, Gupta PK, Sharma A, Bhadoria AS, Gupta P. Evaluation of existing knowledge, attitude, perception and compliance of hand hygiene among health care workers in a Tertiary care centre in Uttarakhand. J Family Med Prim Care. 2020; 9(3): 1620-7.

16. Zakeri H, Ahmadi F, Rafeemanesh E, Afshari Saleh L. The knowledge of hand hygiene among the healthcare workers of two teaching hospitals in Mashhad. Electronic Physician. 2017; 9(8): 5159-65.

17. Calabro K, Bright K, Kouzekanani K. Long-term effectiveness of infection control training among fourth-year medical students. Medical Education Online. 2000; 5(1): 5850.

18. Baier C, Albrecht U-V, Ebadi E, Vonberg R-P, Schilke R. Knowledge about hand hygiene in the Generation Z: A questionnaire-based survey among dental students, trainee nurses and medical technical assistants in training. AJIC: American Journal of Infection Control. 2020; 48: 708-12.

19. Karadag M, Pekin Iseri O, Yildirim N, Etikan I. Knowledge, beliefs and practices of nurses and nursing students for hand hygiene. Jundishapur $\mathbf{J}$ Health Sci. 2016; 8(4). http://dx.doi.org/10.17795/jjhs-36469. 